\title{
EDUCAÇÃO AMBIENTAL: JACUIZINHO/RS - CONHECER, DIAGNOSTICAR PARA PRESERVAR!
}

\author{
Environmental education: Jacuizinho / RS - know, diagnosis to preserve! \\ Marionara Nogueira Fiuza ${ }^{1}$, Mario Luiz Trevisan ${ }^{2}$ \\ ${ }^{1}$ UAB Especialização em Educação Ambiental, UFSM, Santa Maria, RS, Brasil \\ ${ }^{2}$ Departamento de Expressão Gráfica, UFSM, Santa Maria, RS, Brasil (Orientador)
}

Resumo

\begin{abstract}
O presente trabalho teve como objetivo conhecer as características ambientais do Munícipio de Jacuizinho/RS, avaliando as concepções de jovens em idade escolar sobre os pontos positivos e negativos de seu município, instigando os mesmos e seus respectivos professores a partirem em busca de avaliá-lo, analisando as atividades em âmbito local. O procedimento utilizado foi a pesquisa bibliográfica e de campo. Foram aplicados questionários com questões objetivas aos educandos de nível médio e fundamental em duas escolas, uma localizada em âmbito rural e outra em âmbito urbano, e questionário com questões abertas a educadores das respectivas escolas, os quais estão envolvidos com a EA. Buscou-se conhecer a realidade ambiental a qual professores e alunos estão inseridos. Notou-se que os educadores encontram dificuldades na inserção da educação ambiental, relataram a necessidade de qualificação e efetiva participação dos envolvidos. Segundo eles a falta destes elementos acaba dificultando o desenvolvimento e aplicabilidade deste tema. Há a necessidade da participação de todos; a qualificação dos métodos educacionais e dos profissionais envolvidos, desenvolvendo um trabalho em conjunto com enfoque na realidade em que o educando está inserido para que a partir deste conhecimento os mesmos estejam aptos a anal isar as consequências das ações sem planejamento e uso irracional dos recursos naturais.
\end{abstract}

Palavras-chave: Conhecimento. Realidade. Escola. Mediadora. Dificuldades.

Abstract

This study aimed to assess the environmental characteristics of the Municipality of Jacuizinho / RS, assessing young people's views of school age about the strengths and weaknesses of your municipality, urging them and their teachers to leave in search of evaluate it, analyzing the activities at the local level. The procedure used was the bibliographical and field research. Questionnaires were applied with objective questions to primary and secondary level students in two schools, one located in rural areas and in other urban areas, and questionnaire with questions open to educators of their schools, which are involved with EA. He sought to know the environmental reality which teachers and students are entered. It was noted that educators have difficulties in the integration of environmental education, reported the need for training and effective participation of those involved. According to them a lack of these elements makes it difficult to develop and applicability of this theme. There is the need for participation of all; the qualification of educational methods and professionals involved, developing a joint effort focused on reality in which the student is entered so that from this knowledge they are able to analyze the consequences of actions without planning and irrational use of natural resources.

Key words: Knowledge. Reality. School. Mediator. Difficulties. 


\section{Introdução}

A educação ambiental avançou muito nos últimos anos, conquistas foram alcançadas em prol da preservação ambiental. Com a realização de estudos e amparo das legislações criadas, torna-se palpável a necessidade de preservar.

Segundo Guimarães (2007), a postura ambiental, tornou-se necessária levando em consideração a vulnerabilidade que se encontram os recursos naturais devido ao descaso, uso abusivo e sem planejamento dos mesmos, o que na atualidade se torna visível com tamanhas reações com às quais a natureza se encarrega de demostrar ao homem o quão impactante são suas ações, e quão importante e necessária a mudança na formação de seus valores e atitudes, se tratando do meio em que se vive e necessita para a manutenção de sua sobrevivência.

A postura ambiental, portanto, torna-se relevante para a sociedade, considerando que o futuro da humanidade depende de sua interação com o meio. E, devido a gravidade da situação, faz-se necessária a implantação da educação ambiental para as gerações em idade de formação de valores e atitudes, como também para a população em geral. Isso não significa que a escola deva ser a única responsável por trabalhar a educação ambiental, mas sim todos os setores da sociedade, já que todos são responsáveis pelo impacto da ação humana no ambiente (Guimarães, 2007).

Com a necessidade de frear o uso abusivo destes recursos, fez-se necessária a utilização de "delimitadores" para as ações do homem; estes regrados por uma junção de leis, decretos, políticas de ensino, entre inúmeras outras ferramentas, que se tornaram indispensáveis para demonstrar ao ser humano a necessidade de manter o equilíbrio entre a relação homem, economia e meio ambiente, e prevenir que o uso irracional afete a estabilidade e disponibilidade em que os mesmos se encontram.

O trabalho de preservação e conscientização ambiental é árduo e contínuo, o qual conduz ao uso adequado dos recursos naturais. O conhecimento e a informação andam juntos, portanto, é de suma importância a abordagem a respeito da realidade ambiental de maneira local, mas com retrospectivas globais, estes conhecimentos possibilitam uma análise da real situação ambiental do planeta e condicionam o homem ao uso adequado dos mesmos, levando a exploração consciente e sustentável, diminuindo assim os danos ao meio ambiente.

"A cultura ambiental começou a girar em torno da necessidade de sustentar os recursos, mas sua crescente expansão tem sido acompanhada por uma polissemia em torno da qual não há consenso." (STAHEL, 1998 apud DUVOISIN; SOUZA; GALIAZZI, 2003, p.71).

De acordo com Stahel (1998), não há um conceito comum entre a humanidade, em relação as questões ambientais, tendo em vista que existem muitas lacunas nas concepções das pessoas e na aplicabilidade das legislações vigentes.

"Chega-se aos dias de hoje com a maioria da população vivendo em centros urbanos. A água limpa sai da torneira e a suja vai embora pelo ralo, o lixo produzido diariamente é levado da frente das casas sem as pessoas terem a mínima preocupação de saber qual o seu destino. Ou seja, a grande maioria da população não consegue perceber a estreita correlação do meio ambiente, com o seu cotidiano. " (DONELLA,1997 apud ALMEIDA; LOPES, 2012, p.3).

“No comodismo em que a sociedade está inserida, não há preocupação em conhecer a realidade ambiental a qual assola o planeta, além da porta de casa, crendo que suas atitudes não são responsáveis pela degradação a qual os recursos naturais se encontram na atualidade, se eximindo da culpa, acreditando que o homem criou um sistema que se assemelha a natureza, onde tudo se renova automaticamente. Sendo que devido as atividades sem planejamento efetuadas pelo homem, até a natureza vem perdendo esta capacidade. " (DONELLA, 1997 apud ALMEIDA; LOPES, 2012, p.3).

Nesta perspectiva surge a necessidade da inserção da educação ambiental no cotidiano do ser humano, despertar o interesse em conhecer a realidade em que a humanidade vive, os processos necessários para que a mesma chegasse a estrutura em que se vive no presente. Instigá-los a analisar 
os prós e contras do "avanço" da sociedade. Sendo esta uma conformidade da Politica Nacional de Educação Ambiental. Lei n.9.795, de 27 de abril de 1999, que trata do entendimento do papel da educação ambiental, sendo este voltado a conhecer os processos que a humanidade passa a fim da construção de seus valores, atrelando-se com a preservação e conservação do meio ambiente, elementos essenciais para a manutenção da qualidade de vida.

Art. $1^{\circ}$ Entende-se por educação ambiental os processos por meio dos quais o indivíduo e a coletividade constroem valores sociais, conhecimentos, habilidades, atitudes e competências voltadas para a conservação do meio ambiente, bem de uso comum do povo, essencial à sadia qualidade de vida e sua sustentabilidade. (Art. $2^{\circ}$ ) A educação ambiental é um componente essencial e permanente da educação nacional, devendo estar presente, de forma articulada, em todos os níveis e modalidades do processo educativo, em caráter formal e não formal (BRASIL, 1999).

Observando o município de Jacuizinho/RS, nos deparamos com a necessidade de estudá-lo. Conhecer a realidade local deste município em relação às questões ambientais, e a inserção da educação ambiental nas escolas e comunidade.

Propondo esta ideia buscou-se avaliar a situação ambiental vivenciada hoje neste munícipio, a existência ou inexistência, de coleta seletiva de resíduos, tratamento de esgoto e água, inserção destes temas na educação ambiental, dificuldades encontradas para esta inserção nas escolas.

Visando conhecer a realidade local, pontos positivos e negativos, fauna, flora, bioma, conscientização ambiental dos jovens em idade escolar, ressaltando a preservação dos recursos existentes para que os mesmo não se extingam. Trazendo um levantamento de importantes tópicos que podem auxiliar a projetar de maneira adequada as atividades desenvolvidas, induzindo ao uso sustentável dos recursos naturais existentes na região.

\section{Revisão Bibliográfica}

A sociedade faz parte de um conjunto, um sistema, onde todos têm sua função, como em um processo participativo integrado por todas as partes, as quais são indispensáveis para a manutenção da vida no planeta. Neste sentido surge o trabalho da educação ambiental o qual é necessário para que os indivíduos conheçam este sistema e usufruam destes sem comprometer a satisfação das futuras gerações.

“Os seres humanos vivem em um sistema complexo, e a sociedade humana está situada e depende tanto da biosfera como da cultura. Depende do equilíbrio de todo esse sistema para garantir a sobrevivência, portanto não se justifica separar os seres humanos da natureza" (LASZLO, 1987 apud DUVOISIN; SOUZA; GALIAZZI, 2003, p.71).

A educação ambiental traz como propósito estender o conhecimento a respeito da importância da preservação dos recursos naturais para todas as áreas, difundindo a base teórica com a prática, para juntas expandirem seus saberes a toda a comunidade, atuando na realidade em que cada uma está inserida. Sendo esta uma prática educativa que tem como finalidade conscientizar a população da importância do uso racional dos recursos naturais, despertando a consciência, que é compromisso de todos, a conservação e o cuidado com os mesmos, para que esta e as próximas gerações possam fazer uso destes recursos sem degradá-los, buscando o equilíbrio entre homem e natureza, um caminho próximo ao uso sustentável.

"É a forma como as atuais gerações satisfazem as suas necessidades sem, no entanto, comprometer a capacidade de gerações futuras satisfazerem as suas próprias necessidades" (Brundtland apud Scharf, 2004, p.19). 
Segundo o conceito de sustentabilidade, introduzido por Brundtland, deve haver um equilíbrio entre as ações efetuadas pelo homem em relação ao uso dos recursos naturais. Percebe-se deste então a busca pela conscientização, tendo em vista que qualquer atividade humana sobre a natureza, deve ser planejada.

\begin{abstract}
A principal função do trabalho com o tema meio ambiente é contribuir para a formação de cidadãos conscientes, aptos a decidir e atuar na realidade socioambiental de um modo comprometido com a vida, com o bem-estar de cada um e da sociedade, local e global. Para isso é necessário que, mais do que informações e conceitos, a escola se proponha a trabalhar com atitudes, com formação de valores, com o ensino e aprendizagem de procedimentos. E esse é um grande desafio para a educação. Gestos de solidariedade, hábitos de higiene pessoal e dos diversos ambientes, participação em pequenas negociações são exemplos de aprendizagem que podem ocorrer na escola. Assim, a grande tarefa da escola é proporcionar um ambiente escolar saudável e coerente com aquilo que ela pretende que seus alunos apreendam, para que possa, de fato, contribuir para a formação da identidade como cidadãos conscientes de suas responsabilidades com o meio ambiente e capazes de atitudes de proteção e melhoria em relação a ele. (BRASIL, 1998, p.187).
\end{abstract}

Para que haja êxito na aplicabilidade da educação ambiental é indispensável a participação de todos, sendo que todos fazem parte e são responsáveis pela conservação do meio ambiente, e devem participar de maneira positiva em busca de uma convivência harmoniosa, formando conceitos e valores voltados para a preservação dos recursos naturais.

\begin{abstract}
À Educação Ambiental cabe contribuir para o processo de transformação da sociedade atual em uma sociedade sustentável, centrado no exercício responsável da cidadania, que considere a natureza como um bem comum, leve em conta a capacidade de regeneração dos recursos materiais, promova a distribuição equitativa da riqueza gerada e favoreça condições dignas de vida para as gerações atuais e futuras (SADER, 1992 apud GRUENER; DALLACORTE, 2011, p.50).
\end{abstract}

\title{
2.1 Jacuizinho e sua origem
}

Em meados do ano de 1877,foi iniciada a colonização deste município gaúcho. Os povos colonizadores vieram de localidades dos arredores, como Soledade, Cachoeira do Sul e outras. Muitos foram os marcos históricos, entre eles a construção da Igreja Menino Jesus em 1883, a qual encontra-se preservada até os dias atuais. A vila como era chamada deu espaço a vários povos, miscigenando a cultura do local, descendentes de açorianos, italianos, negros e alemães vieram em busca de espaço para o cultivo de alimentos para sua sobrevivência. Assim foram abrindo lavouras para o cultivo de arroz e criação de gado, logo surgiram as primeiras oficinas, olarias, mercearias, dando inicio ao vilarejo o qual apesar de ser um município jovem, emancipado em 1996, oficialmente instalado no ano de 2001, tem mais de 150 anos de história sendo que em 1858, era este distrito de Passo Fundo, logo após Soledade, Espumoso e Salto do Jacuí (JACUIZINHO, 2011).

Por ser um município riquíssimo em sua biodiversidade, diversas espécies de animais fazem parte do cenário, entre elas uma espécie a qual se destacou, pois é apontada como uma das versões da origem do nome do município, o Jacú (aves galinácea) + " $Y$ " = rio com o sufixo luso acrescido ao nome guarani de origem indígena, presente na cultura do município. Outra versão a qual se une a esta é o rio que atravessa a cidade, principal efluente do Rio Jacuí. Originando o diminutivo de Jacuí, o Jacuizinho (JACUIZINHO, 2011).

Por se tratar de um município pequeno em fase de crescimento, riquíssimo em sua biodiversidade, surge a necessidade de monitorá-lo, estudar os passos dados para que não perca a essência do nome deste município, seus recursos naturais, os quais devem ser preservados. 
A inserção da educação ambiental se faz necessária para que a comunidade perceba que o modo de vida levado em sua cidade, interfere de maneira positiva ou negativa, não só neste local, mas em todo mundo. Sendo que não significa por residirem em um município relativamente pequeno, e ainda com grande disponibilidade de recursos naturais, que esta realidade não possa tornar-se igual as demais vivenciadas nos grandes centros. Neste sentido a educação ambiental busca envolver as pessoas na transformação e quebra de paradigmas, fazendo-as perceber a importância da preservação dos recursos para sua sobrevivência, tornando-as participativas e conscientes da sua relação com o meio ambiente.

\subsection{Características ambientais do Município de Jacuizinho}

\subsubsection{Recursos hídricos}

Quanto à caracterização dos recursos hídricos conforme Plano Municipal Ambiental (2011), o município possui vasta disponibilidade destes recursos figura 3, pertence à bacia hidrográfica do Alto Jacuí, figura 1, das bacias hidrográficas. Seus cursos d'água são compostos por rios, arroios, lajeados, e barragens, figura 2. As águas, superficiais do município estão hierarquizadas em um conjunto de sub-bacias.

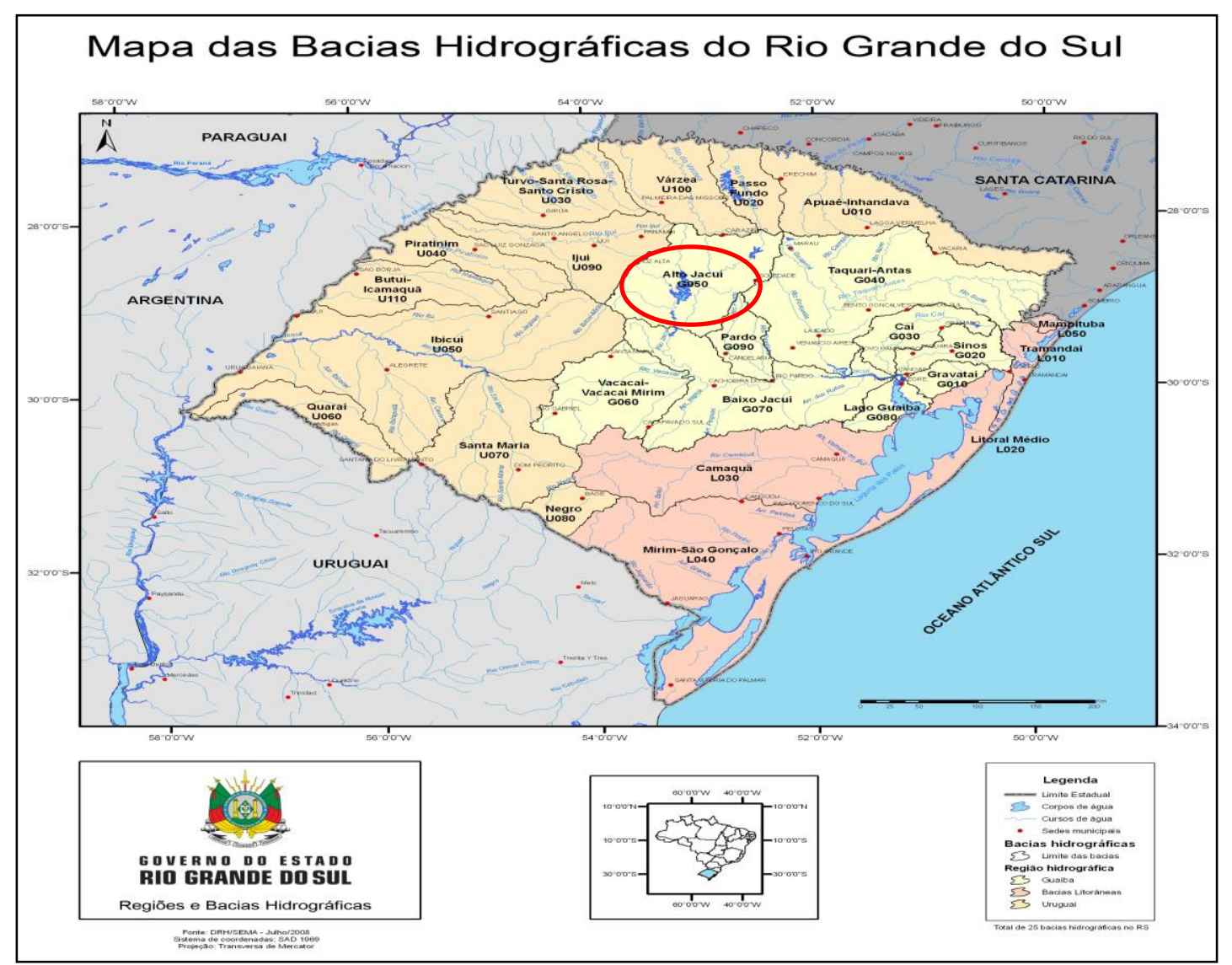

Figura 1-Mapa das Bacias Hidrográficas do Rio Grande do Sul.

Fonte: SEMA/RS

Os principais cursos de água componentes desta bacia são os rios Jacuí, Jacuí Mirim, Jacuizinho, dos Caixões e Soturno. O Rio Jacuí, de maior destaque, tem como afluentes mais 
importantes da margem direita o Rio Glória, o Rio Colorado, o Rio Jacuí Mirim e os da margem esquerda o Arroio Butiá, o Rio Jacuizinho e o Rio dos Caixões. Os principais usos da água se destinam à irrigação, dessedentação animal e consumo humano (JACUIZINHO, 2011).

O município está inserido na região de aqüífero, denominado Sistema Aqüífero Serra Geral I. Este aqüífero ocupa a parte centro-oeste da região.

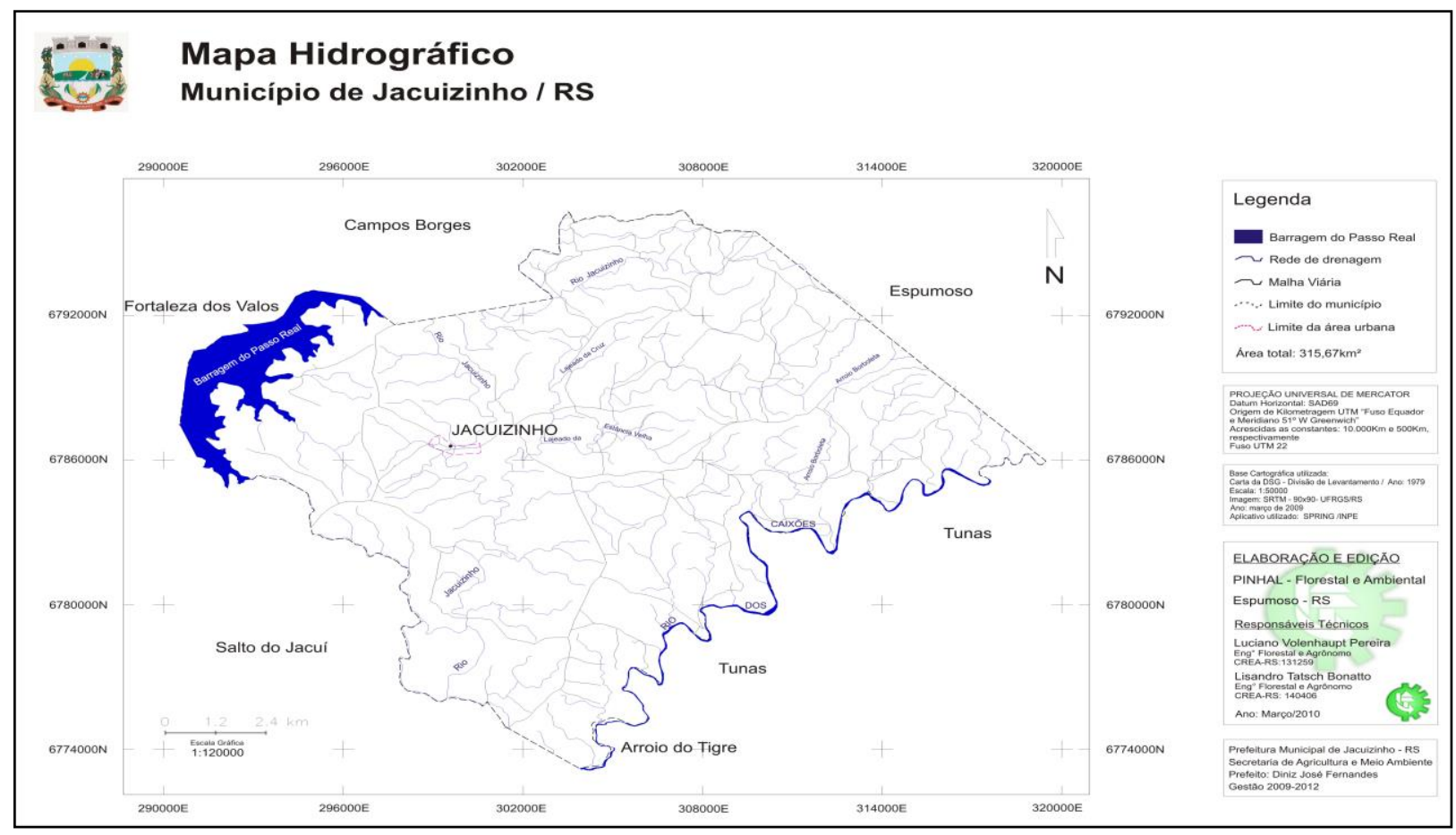

Figura 2- Mapa Político Administrativo do Município.

Fonte: Plano Municipal Ambiental (2011).

É necessário preservar os recursos naturais, evitando a contaminação, e prevenindo sua extinção. A educação ambiental com auxilio da legislação vigente visa sensibilizar para a importância da preservação dos recursos hídricos, e demais recursos naturais, os quais são indispensáveis para a sobrevivência das espécies, inclusive a humana. A EA, auxilia na concepção de valores, possibilitando aos indivíduos conhecer e analisar diferentes situações em relação as atividades exercidas pelo homem sobre a natureza. Possibilitando a estes planejar suas ações na procura de melhoria na qualidade de vida.

Na busca pela manutenção da qualidade dos recursos naturais, a inserção da EA é uma ferramenta de suma importância, pois possibilita a sociedade uma visão ampla de sua responsabilidade com relação a preservação dos recursos oferecidos pela natureza, inclusive a água, necessária para manutenção da vida na terra. Neste sentido a política nacional de recursos hídricos visa:

I - assegurar à atual e às futuras gerações a necessária disponibilidade de água, em padrões de qualidade adequados aos respectivos usos; II - a utilização racional e integrada dos recursos hídricos, incluindo o transporte aquaviário, com vistas ao desenvolvimento sustentável; III - a prevenção e a defesa contra eventos hidrológicos críticos de origem natural ou decorrentes do uso inadequado dos recursos naturais (BRASIL, 1997). 
Assegurar a disponibilidade e a qualidade deste e demais recursos naturais tornou-se primordial, tendo em vista o uso irracional e sem planejamento efetuado pelo homem, o qual acarreta inúmeras transformações no ambiente.

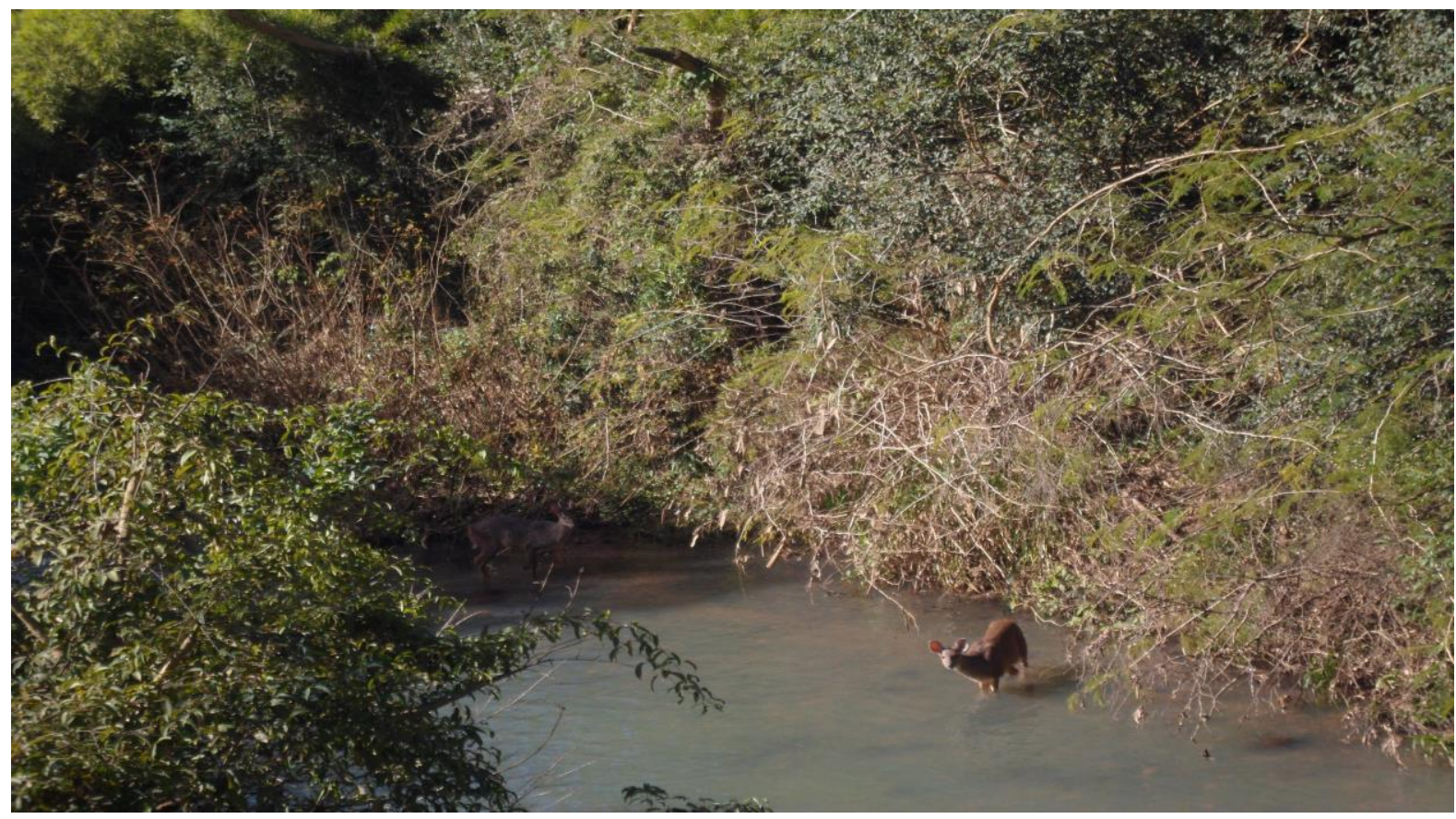

Figura 3 - Lajeado Estância Velha- amostragem de um dos cursos d'água e diversidade da fauna encontrada no Município. Fonte: "acervo da autora"

Segundo Sistema Nacional de Informações sobre Saneamento Diagnóstico de Serviços de Água e Esgotos, 2013 - SNIS, o município possui 400 ligações de água, com 395 economias ativas, 80 destas são micro medidas. Com extensão de $70 \mathrm{~km}$ de rede de água. Conforme Plano Municipal de Saneamento básico 2014 foram verificados alguns problemas no fornecimento de água conforme figura 4.

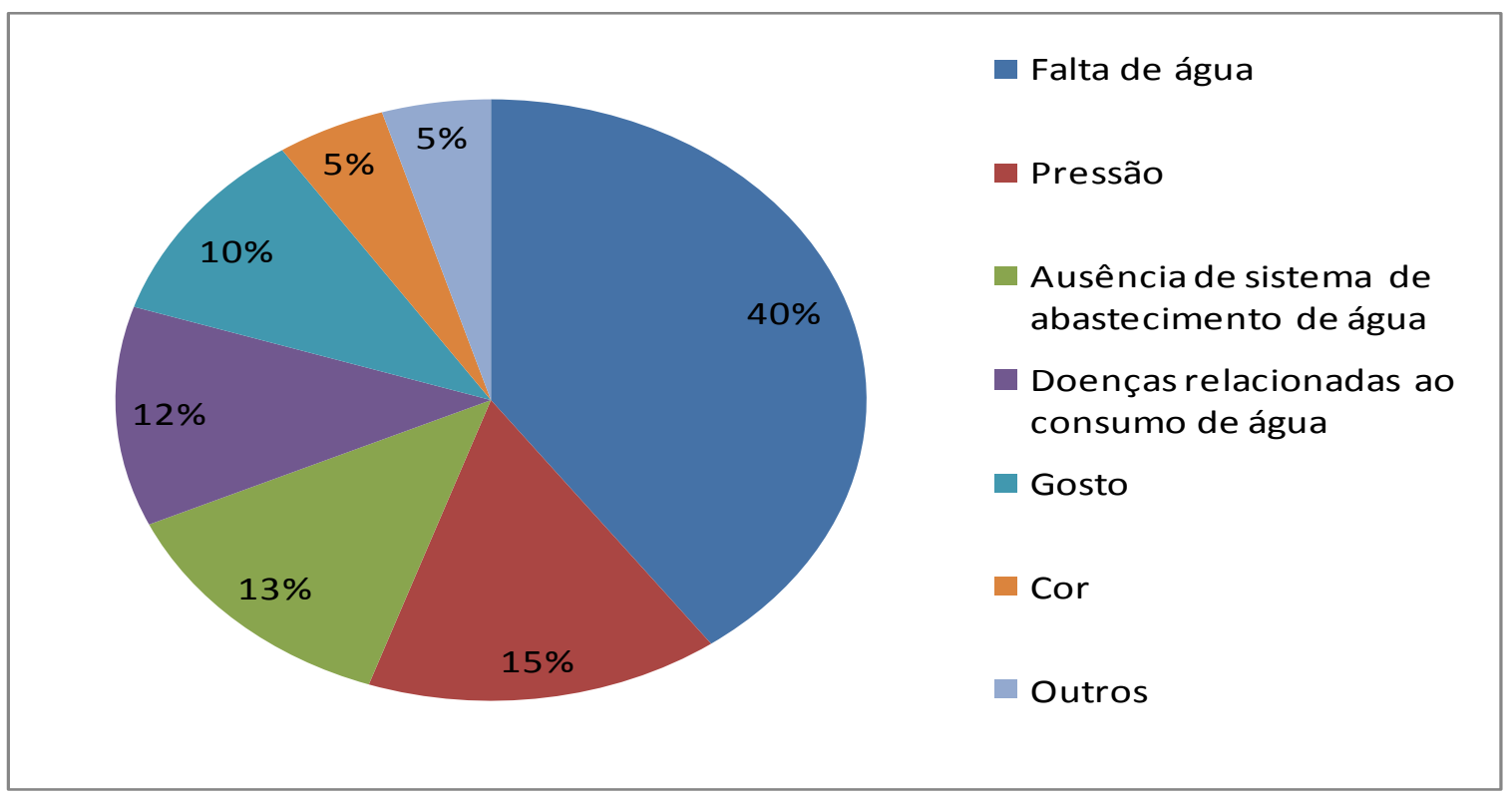

Figura 4 - Problemas verificados no fornecimento de água no município de Jacuizinho, segundo pesquisa realizada com habitantes do local - Ano 2014 Fonte: Plano Municipal de Saneamento básico (2014). 
Pode-se verificar na figura 4, resultado do diagnóstico do Plano Municipal de Saneamento Básico, que $40 \%$ dos munícipes apontaram a falta de água, possivelmente se tratando de água tratada e problemas com interrupções diárias no abastecimento, sendo que conforme dados do plano municipal de saneamento básico, o município não possui $100 \%$ das residências ligadas a rede de abastecimento e conforme dados SNIS (2013) foram relatadas 35 paralisações com duração igual ou superior a 6 horas/dia.

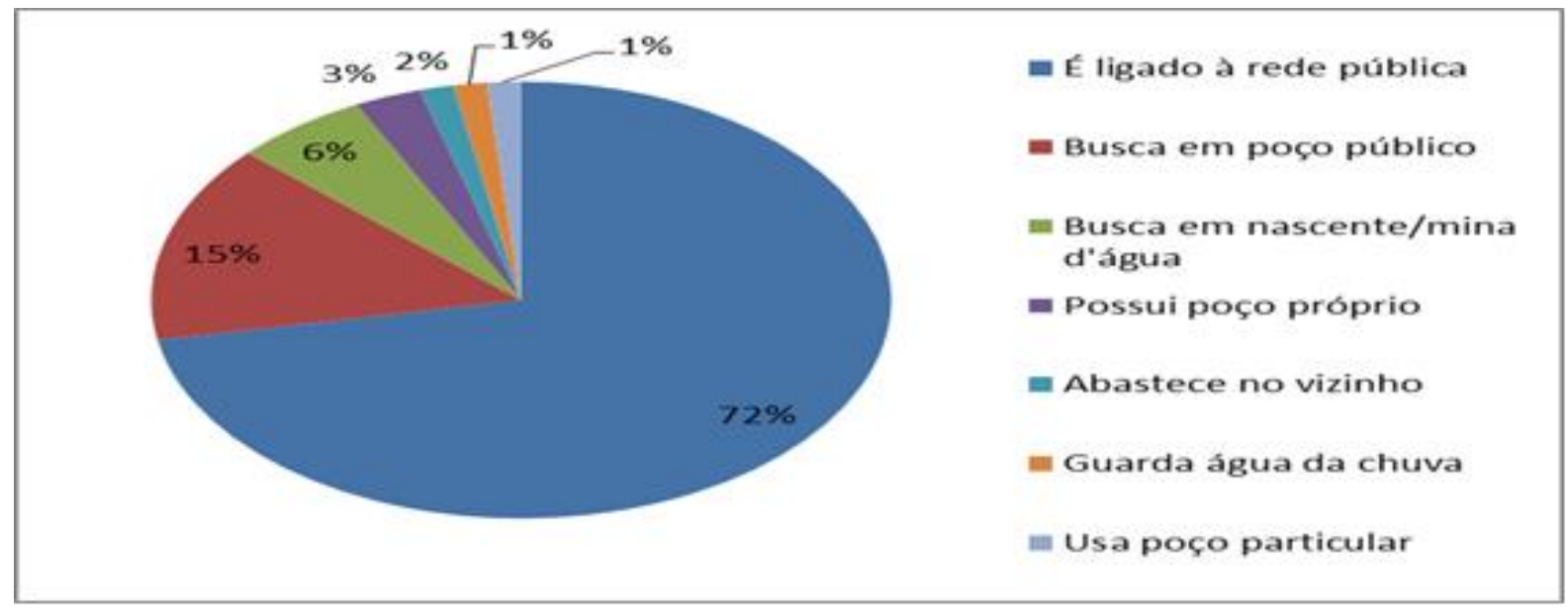

Figura 5- Principais Fontes de Abastecimento de água no município de Jacuizinho, segundo pesquisa realizada com habitantes do local - Fonte: Plano Municipal de Saneamento Básico (2014).

Conforme figura 5, pode-se observar as fontes de abastecimento de água utilizadas no município. Sendo que $72 \%$ dos munícipes tem suas residências ligadas a rede pública de abasteciemto.

É utilizada a exploração de fontes subterrâneas, para abastecimento de água, totalizando um sistema com 15 poços, que atentem as comunidades, sendo dois destes localizados em zona urbana e demais em zona rural. Sendo que a população residente na zona rural é de 1.954 habitantes e apenas 553 habitantes na zona urbana (JACUIZINHO, 2014).

Segundo Plano Municipal de Saneamento Básico, e pesquisa efetuada no departamento municipal de meio ambiente, apenas quatro poços possuem outorga, tabela 2, a documentação dos demais foram encaminhadas ao Departamento de Recursos Hídricos do Estado (DRH), sendo que as comunidades foram divididas em macrozonas, tabela 1, para melhor analisar as redes de distribuição, conforme relatado anteriormente com fonte do SNIS (Sistema Nacional de Informações sobre Saneamento Básico), há $70 \mathrm{Km}$ de extensão de rede de água, em todo o perímetro municipal (JACUIZINHO, 2014).

Tabela 1 - Famílias atendidas pelo abastecimento de água nas macrozonas rurais.

\begin{tabular}{cccc}
\hline & \multicolumn{2}{c}{ MACROZONA RURAL 1 } & Famílias \\
Comunidade & № de poços & Localização & atendidas \\
FLECHA AZUL & $\mathbf{1}$ & Residência 01 & $\mathbf{4 0}$ \\
ORALINA BAIXA & $\mathbf{1}$ & Residência 02 & $\mathbf{2 5}$ \\
BELA VISTA 1 & $\mathbf{1}$ & Residência 03 & $\mathbf{3 2}$ \\
BELA VISTA 2 & $\mathbf{1}$ & Residência 04 & $\mathbf{4 0}$ \\
RINCÃO SÃO LUIZ & $\mathbf{1}$ & Residência 05 & $\mathbf{4 0}$ \\
SERRA DOS & $\mathbf{1}$ & Residência 06 & $\mathbf{4 2}$ \\
ENGENHOS & $\mathbf{1}$ & & \\
\hline
\end{tabular}




\begin{tabular}{cccc}
\hline & \multicolumn{2}{c}{ MACROZONA RURAL 2 } & $\mathbf{1 2}$ \\
\hline QUILOMBOLA & $\mathbf{1}$ & Residência 07 & $\mathbf{1 0}$ \\
NOVO HORIZONTE & $\mathbf{2}$ & Residência 08 & $\mathbf{0 9}$ \\
RINCÃO DOS & & Residência 09 & $\mathbf{4 2}$ \\
COSTAS & $\mathbf{1}$ & Residência 10 & $\mathbf{5 0}$ \\
BANGÚ & $\mathbf{1}$ & Residência 11 & $\mathbf{4 0}$ \\
BORBOLETA & $\mathbf{1}$ & Residência 12 & $\mathbf{2 9}$ \\
PANTANINHO & $\mathbf{1}$ & Residência 13 & $\mathbf{5 5}$ \\
LINHA PEREIRA & $\mathbf{1}$ & Residência 14 \\
SÃO JORGE & $\mathbf{1}$ & &
\end{tabular}

Fonte: Plano Municipal de Saneamento Básico (2014).

Tabela 2 - Relação dos poços outorgados pelo DRH/RS

\begin{tabular}{|c|c|c|c|}
\hline \multicolumn{4}{|c|}{ MACROZONA RURAL 1} \\
\hline Comunidade & $\begin{array}{c}\text { Capacidade } \\
\text { de resevação } \\
\left(\mathrm{m}^{3}\right)\end{array}$ & Vazão (m³/dia) & Localização (Coordenadas) \\
\hline SERRA DOS ENGENHOS & 15 & 72 & $28^{\circ} 59^{\prime} 21,34523^{\prime \prime} \mathrm{S} / 5258^{\prime} 38,2^{\prime \prime} \mathrm{W}$ \\
\hline \multicolumn{4}{|c|}{ MACROZONA RURAL 2} \\
\hline NOVO HORIZONTE & & 160 & $\begin{array}{c}29^{\circ} 06^{\prime} 39,07^{\prime \prime} \mathrm{S} / 52^{\circ} 59^{\prime} 20,71^{\prime \prime} \mathrm{W} \\
29^{\circ} 03^{\prime} 26^{\prime \prime} \mathrm{S} / 52^{\circ} 57^{\prime} 39,5^{\prime \prime} \mathrm{W}\end{array}$ \\
\hline RINCÃO DOS COSTAS & & 40 & $29^{\circ} 03^{\prime} 13^{\prime \prime} \mathrm{S} / 53^{\circ} 00^{\prime} 26^{\prime \prime} \mathrm{W}$ \\
\hline PANTANINHO & & 56 & $2^{\circ} 01^{\prime} 10,2^{\prime \prime} \mathrm{S} / 52^{\circ} 53^{\prime} 10^{\prime \prime} \mathrm{W}$ \\
\hline
\end{tabular}

Fonte: Plano Municipal de Saneamento Básico (2014).

Conforme plano municipal de saneamento, na macrozona urbana são atendidos com dois poços 178 domicilios, a capacidade de reservação deste é de 10.000 e 15.000 litros. Não há hidrometros nas residências, em área rural e urbana. Sendo atribuída tarifa única, disciplinada pelo decreto municipal no 71/2005. O monitoramento da qualidade da água destas fontes de abastecimento são realizadas por uma empresa terceirizada que efetua análise mensal dos poços.

\subsection{Caracterização da Fauna e flora do Município}

\subsubsection{Caracterização da Flora}

O município de Jacuizinho está localizado na região do Planalto Médio que é limitado ao Norte pela região do Alto Uruguai, ao Sul pela Depressão Central e Leste pela Encosta Superior ao Nordeste, na região são encontradas formações vegetais da Floresta Ombrófila Mista e Floresta de Galeria que acompanha os cursos de água, também há a existência de fragmentos de campo nativo, onde predomina a cobertura rala de gramíneas, o município faz parte do bioma Mata Atlântica, o qual é conhecido pela presença de diversas espécies animais e vegetais, riquíssimo em biodiversidade (JACUIZINHO, 2011). 
Muitas modificações ocorreram na vegetação da região devido ao aumento nas áreas de cultivo, portanto o município possui uma vasta área de cobertura nativa, com grande diversidade de espécies nativas, inclusive podendo ser encontradas espécies consideradas em extinção no Estado do Rio Grande do Sul, como o pinheiro brasileiro (Araucaria angustifolia) e canelas pertencentes ao gênero Ocotea (JACUIZINHO, 2011).

As formas de vegetação encontradas no município fazem parte das florestas de galeria as quais são formações florestais que acompanham os cursos de água começando sub-arbustivas nas fontes, desenvolvendo-se na encosta seca e rochosa e terminando em matas de regular extensão e altura. A floresta ombrófila mista, que se mistura à savana, no planalto é formada de espécies de araucária (Araucaria angustifolia), no estrato emergente, as canelas (Ocotea sp), camboatás (Cupania sp), pinheiro - bravo (Podocarpos lamberti) e o pessegueiro-bravo (Prunus sellowii) no estrato dominante. Na submata, a aroeiras (Schinus mole e terebinthifolius), o guamirim (Gomidesia palustris), o cambuí (Myrciaria sp), e a erva-mate (Ilex paraguariensis), entre outras. E a floresta nativa do planalto basáltico com ocorrência de araucária com algumas características próprias (JACUIZINHO, 2011).

\subsubsection{Caracterização da Fauna}

A fauna do município em questão é caracterizada pela combinação da fauna ocorrente em áreas abertas, como formações de campo nativo e capoeirões e pela fauna ocorrente em florestas fechadas, elementos fitogeográficos típicos da região, que oferecem condições para o estabelecimento de espécies com características, modo de vida e, muitas vezes, origem diferente, vindo a refletir na grande diversidade de espécies encontradas (JACUIZINHO, 2011).

O município possui uma vasta diversidade de espécies que compõem a fauna, a qual é formada principalmente por aves, mamíferos, insetos, répteis e anfíbios, algumas dessas espécies, que se encontram preservadas no município são ameaçadas de extinção nos demais, sendo que este se tornou um refúgio para essas espécies, pois ainda preserva seus habitats.

Algumas espécies da fauna encontradas no munícipio são: andorinha-pequena-de-casa (Notiochelidon cyanoleuca), anu-preto (Crotophaga ani), anu-branco (Guira guira), beija-flor-de-papobranco (Leucochloris albicollis), bem-te-vi (Pitangus sulphuratus), marreca (Jacana jacana), canário-da-terra (Sicalis flaveola), cardeal (Paroaria coronata), caturrita (Myiopsitta monachus), chopim (Gnorimopsar chopi), corruíra (Troglodytes musculus), coruja do campo (Athene cunicularia), corujinha-do-mato (Megascops choliba), ema (Rhea americana), garça-branca- pequena (Egretta thula), gavião-carijó (Rupornis magnirostris), gralha-azul (Cyanocorax caeruleus), gralha-picaça (Cyanocorax chrysops), jacu (Penelope obscura). (JACUIZINHO, 2011).

\subsection{Resíduos sólidos e esgotamento sanitário}

\subsubsection{Coleta e destinação Resíduos sólidos}

No município não é realizada coleta seletiva, a mesma ocorre sem a segregação dos rejeitos, sendo esta efetuada apenas no perímetro urbano, os resíduos são coletados por uma empresa terceirizada a qual envia estes a um aterro sanitário a aproximadamente $200 \mathrm{Km}$ da cidade (JACUIZINHO, 2014).

Conforme lei Federal no 12.305/2010, “ a gestão integrada de resíduos sólidos trata do conjunto de ações voltadas a busca de soluções para os resíduos sólidos, de forma a considerar as dimensões política, econômica, ambiental, cultural e social, com controle social e sob a premissa do desenvolvimento sustentável". 
Conforme dados apresentados no diagnóstico do Plano Municipal de Saneamento Básico, (2014), são coletados $7.500 \mathrm{Kg}$ de resíduo sólido por mês, ou seja, 13,35 Kg/hab. mês. Destes, $50 \%$ é de matéria orgânica, $20 \%$ rejeito e 30\% recicláveis. Apenas $22 \%$ dos habitantes são contemplados pela coleta de resíduos sólidos domiciliares e 78\% não disponibilizam deste serviço. Em conformidade com a politica nacional de resíduos sólidos Art. 13ㅜㅜ que classifica os resíduos da seguinte forma:

\begin{abstract}
a) resíduos domiciliares: os originários de atividades domésticas em residências urbanas; b) resíduos de limpeza urbana: os originários da varrição, limpeza de logradouros e vias públicas e outros serviços de limpeza urbana; c) resíduos sólidos urbanos: os englobados nas alíneas "a" e " $\mathrm{b}$ "; d) resíduos de estabelecimentos comerciais e prestadores de serviços: os gerados nessas atividades, excetuados os referidos nas alíneas " $b$ ", " $\mathrm{e}$ ", "g", “ $h$ " e "j"; e) resíduos dos serviços públicos de saneamento básico: os gerados nessas atividades, excetuados os referidos na alínea " $c$ "; f) resíduos industriais: os gerados nos processos produtivos e instalações industriais; g) resíduos de serviços de saúde: os gerados nos serviços de saúde, conforme definido em regulamento ou em normas estabelecidas pelos órgãos do Sisnama e do SNVS; h) resíduos da construção civil: os gerados nas construções, reformas, reparos e demolições de obras de construção civil, incluídos os resultantes da preparação e escavação de terrenos para obras civis; i) resíduos agrossilvopastoris: os gerados nas atividades agropecuárias e silviculturais, incluídos os relacionados a insumos utilizados nessas atividades; j) resíduos de serviços de transportes: os originários de portos, aeroportos, terminais alfandegários, rodoviários e ferroviários e passagens de fronteira; k) resíduos de mineração: os gerados na atividade de pesquisa, extração ou beneficiamento de minérios (BRASIL, 2010).
\end{abstract}

O sistema de coleta de resíduos sólidos domiciliares (RSD) contempla cerca de 553 habitantes numa frequência de duas vezes por semana. As localidades da área rural não são atingidas pelo serviço, ou seja, aproximadamente 1954 habitantes não dispõem do serviço de coleta dos resíduos domiciliares. A prática mais adotada pelos moradores sem coleta é a queima dos resíduos secos e a compostagem em hortas dos resíduos orgânicos (JACUIZINHO, 2014).

\title{
2.4.2. Coleta e tratamento de esgoto
}

O município não disponibiliza de coleta e tratamento de esgoto, o destino do esgoto doméstico é o sistema de fossa com poço negro, tanto em área urbana quanto na rural (composto geralmente com rocha de origem basáltica), cuja característica é de infiltração de efluente no solo, constituindo focos de contaminação ou problemas com o ambiente ou a vizinhança, $17 \%$ das famílias têm o esgoto em valas a céu aberto (JACUIZINHO, 2014).

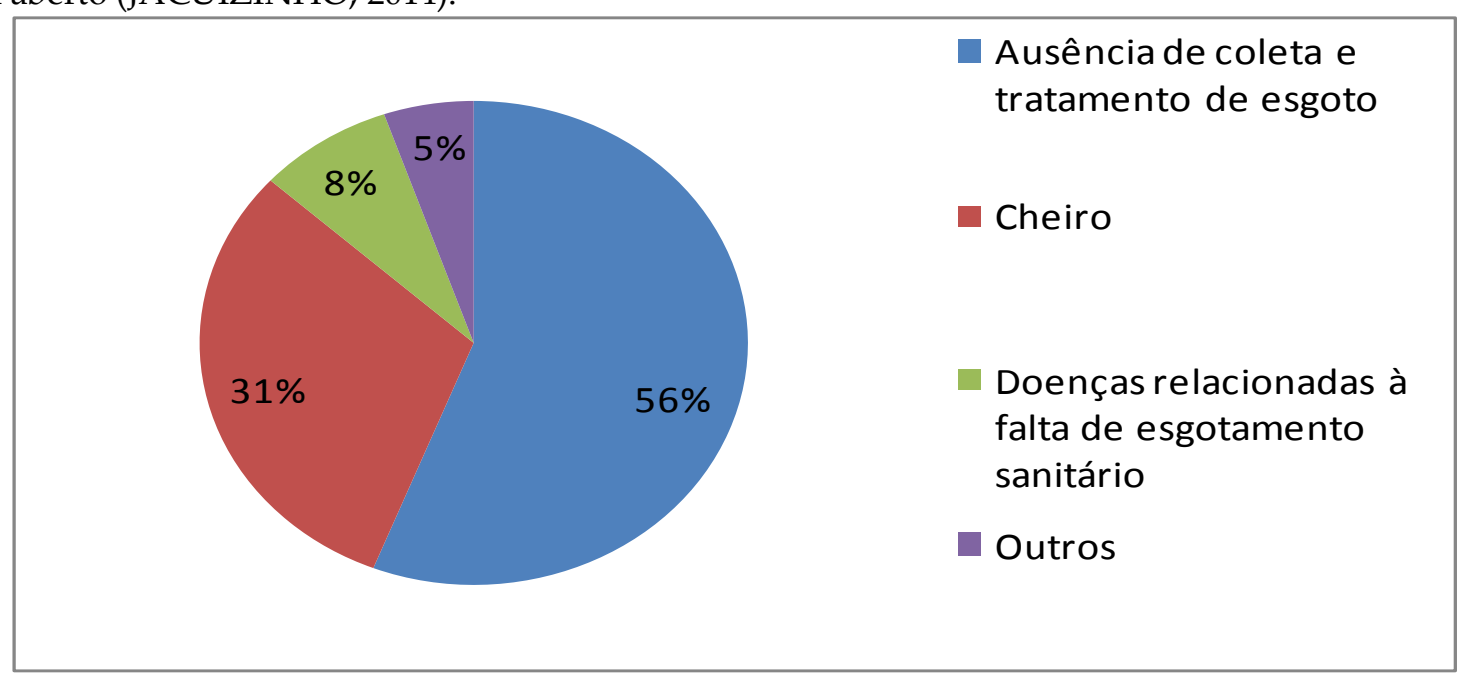

Figura 6 - Problemas verificados no esgotamento sanitário

Fonte: Plano Municipal de Saneamento básico (2014). 
Conforme Plano Municipal de Saneamento Básico, figura 6, a população apresentou como principais problemas relacionados a ausência de coleta e tratamento deste resíduo, os entupimentos, mau cheiro, vazamentos e doenças relacionadas a falta de esgotamento sanitário.

Problemas os quais assolam os grandes e pequenos centros o que difere é a proporção. Na busca por sanar este problema, criou-se uma legislação própria, incentivando a humanidade na busca por alternativas que atenuem o impacto que suas ações causam ao meio ambiente. Neste sentido a Politica Federal de Saneamento Básico busca em seus princípios.

\begin{abstract}
Art. 49. I - contribuir para o desenvolvimento nacional, a redução das desigualdades regionais, a geração de emprego e de renda e a inclusão social; II - priorizar planos, programas e projetos que visem à implantação e ampliação dos serviços e ações de saneamento básico nas áreas ocupadas por populações de baixa renda; III proporcionar condições adequadas de salubridade ambiental aos povos indígenas e outras populações tradicionais, com soluções compatíveis com suas características socioculturais; IV - proporcionar condições adequadas de salubridade ambiental às populações rurais e de pequenos núcleos urbanos isolados; V assegurar que a aplicação dos recursos financeiros administrados pelo poder público dê-se segundo critérios de promoção da salubridade ambiental, de maximização da relação benefício-custo e de maior retorno social; VI incentivar a adoção de mecanismos de planejamento, regulação e fiscalização da prestação dos serviços de saneamento básico; VII - promover alternativas de gestão que viabilizem a auto-sustentação econômica e financeira dos serviços de saneamento básico, com ênfase na cooperação federativa; VIII - promover o desenvolvimento institucional do saneamento básico, estabelecendo meios para a unidade e articulação das ações dos diferentes agentes, bem como do desenvolvimento de sua organização, capacidade técnica, gerencial, financeira e de recursos humanos, contempladas as especificidades locais; (BRASIL, 2007).
\end{abstract}

Princípios que priorizam o planejamento, a adoção de tecnologias que incentivam a difusão de conhecimento e ações proporcionando condições adequadas de salubridade ambiental aos povos.

\title{
3 METODOLOGIA
}

\subsection{Caracterização do município de Jacuizinho}

A necessidade da preservação dos recursos naturais e da redução ou minimização dos impactos ambientais traz a imagem da poluição gerada nos grandes centros e metrópoles. Considerando que o ser humano é parte de um todo, ações mal planejadas podem refletir em reações em qualquer parte do planeta, logo, deve-se pensar no local para obter resultados globais.

Nesta perspectiva, em análise o município de Jacuizinho, o qual possui aproximadamente 2.507 habitantes, com uma extensão territorial de $315,67 \mathrm{~km} 2$. A economia é baseada principalmente na agropecuária.

O Município localiza-se a $300 \mathrm{~km}$ da capital do estado do Rio Grande Do Sul, Porto Alegre, fazendo parte da região do planalto médio, faz divisa com os municípios de Tunas, Espumoso, Arroio do Tigre, Fortaleza dos Valos, Salto do Jacuí e Campos Borges. Integra um bioma riquíssimo em biodiversidade, o mata atlântica, que possui em suas principais características uma vasta e bela formação vegetal. Que possibilita a existência de rica biodiversidade, com presença de diversas espécies animais e vegetais.

\subsection{Caracterização da pesquisa}

O presente trabalho objetivou o levantamento de dados a fim de conhecer a realidade ambiental do Município de Jacuizinho/ RS, em relação a prática da educação ambiental. Realizou-se uma pesquisa com levantamentos de dados de maneira que foram aplicados questionários em duas escolas, uma em âmbito rural e outra urbano, com perguntas objetivas aos alunos, e questionário descritivo aos 
professores, sobre temas inerentes a educação ambiental. Buscando conhecer a realidade ambiental a qual professores e alunos estão inseridos.

Contabilizou-se um total de 28 questionários disponibilizados em dois modelos aos alunos, levando em consideração o nível de conhecimento das turmas, sendo ambos com a mesma finalidade, portanto com linguagens diferenciadas para facilitar a compreensão dos educandos.

No primeiro momento inicia-se com uma conversa com esclarecimento da finalidade a qual os mesmos estão sendo expostos, logo após a aplicação do questionário. Sendo este aplicado a alunos de $5^{\mathbf{o}}$ ano do ensino fundamental de uma escola em zona rural e outra em zona urbana, ambos com a mesma linguagem, em outro momento segue com aplicação de um questionário a alunos de $9^{\circ}$ ano do ensino fundamental de escola em zona rural e $3^{\circ}$ ano de ensino médio de escola em zona urbana.

Aos professores foram disponibilizados questionários dissertativos, a amostragem realizada com quatro educadores, dois de um escola em zona rural e dois de escola em zona urbana. Os mesmos foram entregues e retomados com as resposta. Ambos professores lecionam ou desenvolvem projetos relacionados com a área ambiental em turmas de ensino médio e fundamental.

\subsection{Caracterização das escolas e turmas}

O município possui seis escolas municipais, sendo cinco em zona rural e uma em zona urbana todas contemplam o ensino fundamental; e uma estadual em zona urbana a qual contempla o nível médio.

Destas, foram escolhidas para aplicar os questionários, mediante autorização dos pais dos educandos, uma de nível fundamental em zona rural com 72 alunos matriculados, a qual fica a 15 quilômetros da sede do município. Os questionários foram aplicados a alunos do $5^{\mathrm{o}}$ ano do ensino fundamental, turma com quatro alunos, todos se faziam presentes e $\mathbf{9}^{\mathbf{o}}$ ano, turma com oito alunos sendo que se faziam presentes seis. E na escola Estadual localizada em zona urbana, no centro da sede do município esta com 205 alunos. O questionário foi aplicado a oito alunos do $5^{\mathbf{o}}$ ano do ensino fundamental, e dez alunos do ensino médio. No capitulo a seguir faz-se a discussão dos resultados.

\section{Resultados e discussão}

Após a organização dos dados obtidos através das respostas fez-se a interpretação e a discussão de forma a apontar carências encontradas em âmbito local. Fomentar a discussão sobre a educação ambiental nas escolas, apontar dificuldades encontradas pelos educadores em relação a inserção da educação ambiental no cotidiano escolar, e conhecer dificuldades e desafios na aplicabilidade deste estudo de notável importância para a humanidade.

Segundo Guimarães (2007), a postura ambiental é necessária considerando o futuro da humanidade, a formação de valores direcionados a temática ambiental, tanto para as gerações em idade escolar, como a toda a população, visando urgentemente a mudança de hábitos. No entanto para que isto ocorra é indispensável conhecer a realidade local.

\subsection{Escola Rural e Urbana- alunos $5^{\circ}$ ano}

Os questionários foram aplicados com propósito de conhecer a realidade que os alunos estão inseridos e analisar as suas concepções sobre a educação ambiental, sendo com quatro alunos do $5^{\underline{0}}$ ano da escola localizada na zona rural, todos com idade entre 10 e 12 anos. Dos alunos entrevistados desta escola 100\% moram na zona rural. Quando perguntados se os mesmos já conheciam sobre educação ambiental, $25 \%$ responderam positivamente e $75 \%$ negativamente. Aos que deram resposta positiva, responderam onde ouviram falar, $100 \%$ dos alunos responderam na televisão. 
O mesmo questionário foi aplicado com alunos em uma escola na zona urbana, com oito alunos todos com idade entre 10 e 12 anos, onde $25 \%$ residem na zona rural e $75 \%$ na zona urbana quando perguntados sobre educação ambiental 100\% já ouviram falar, e 100\% responderam na escola, pelo professor.

Tabela 3 - O que é educação ambiental para você?

\begin{tabular}{|c|c|c|}
\hline & $5^{\circ}$ ano Zona urbana(\%) & $5^{\mathrm{o}}$ ano Zona Rural(\%) \\
\hline $\begin{array}{l}\text { Estudo que ajuda o homem a conhecer e } \\
\text { preservar a natureza. }\end{array}$ & 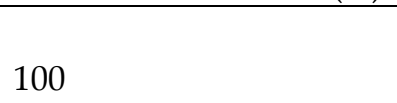 & 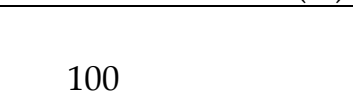 \\
\hline $\begin{array}{l}\text { Estudo sem importância, o qual não traz } \\
\text { conhecimento algum. }\end{array}$ & 0 & 0 \\
\hline $\begin{array}{l}\text { Estudo da matéria de ciências o qual não traz } \\
\text { benefício algum para minha vida. }\end{array}$ & 0 & 0 \\
\hline
\end{tabular}

Quando perguntados sobre o que é educação ambiental tabela 3, 100\% dos alunos do 5o ano de escola em zona urbana e também da rural responderam que é estudo que ajuda o homem a conhecer e preservar a natureza.

Tabela 4 - Em sua escola você estuda sobre a prática de educação ambiental. Caso sim, como?

\begin{tabular}{lcc}
\hline & $5^{\circ}$ ano Zona Rural (\%) & $5^{\circ}$ ano Zona Urbana (\%) \\
\hline Pesquisas em livros & 0 & 0 \\
Palestras & 0 & 0 \\
Trabalhos em grupo & 0 & 25 \\
Aulas com passeios em contato com a natureza & 100 & 75 \\
\hline
\end{tabular}

Para $100 \%$ dos alunos do $5^{\circ}$ ano da escola localizada na zona rural, a prática da educação ambiental ocorre, conforme tabela 4 , em aulas com passeio em contato com a natureza. Já os alunos da zona urbana, $75 \%$ apontaram como os demais da escola de zona rural, aulas com passeios em contato com a natureza e $25 \%$ com trabalhos em grupo.

Tabela 5 - Em sua casa há coleta de resíduos/lixo?

\begin{tabular}{lcc}
\hline & $5^{\circ}$ ano Zona Rural (\%) & $5^{\circ}$ ano Zona Urbana (\%) \\
\hline Sim & 0 & 75 \\
Não & 100 & 25 \\
\hline
\end{tabular}

A tabela 5 mostra que, $100 \%$ dos alunos entrevistados da zona rural, não possuem coleta de resíduos, e na zona urbana $75 \%$ disponibilizam de coleta, ou seja, apenas os que residem em zona urbana, os $25 \%$ que alegaram não possuir coleta estudam na zona urbana mas residem na rural, o que corrobora com os dados levantados pelo plano municipal saneamento básico onde $78 \%$ da população apontou que não é contemplada pela coleta. 
Tabela 6 - Caso não. Qual o destino do lixo seco ( plástico, papel...)?

\begin{tabular}{lll}
\hline & $5^{\circ}$ ano Zona Rural(\%) & $5^{\circ}$ ano Zona Urbana (\%) \\
\hline Queimado & 75 & 100 \\
Enterrado & 25 & 0 \\
Fica disposto no quintal a céu aberto & 0 & 0 \\
\hline
\end{tabular}

Conforme tabela 6, fazendo uma análise dos $25 \%$ que relataram não possuir coleta, (alunos do 5 o ano da escola em zona urbana), 100\% destes relatou que o destino do resíduo seco é a queima. E do total de $100 \%$ que apontam não possuir coleta, (alunos de $5^{\circ}$ ano de zona rural), $75 \%$ efetuam a queima e $25 \%$ relatou ser enterrado. Sendo este percentual relacionado com o apresentado no Plano Municipal de Saneamento, o qual refere que a pratica adotada pelos moradores que não possuem coleta é a queima dos resíduos secos e o método de compostagem em hortas dos orgânicos.

Tabela 7 - De onde vem a água que você usa em sua casa?

\begin{tabular}{lll}
\hline & $5^{\underline{0}}$ ano Zona Rural (\%) & $5^{\mathbf{o}}$ ano Zona Urbana (\%) \\
\hline Rio/córrego & 0 & 0 \\
Nascente olho d'água & 25 & 12,5 \\
Poço próprio & 50 & 0 \\
Captura da chuva & 0 & 0 \\
Rede pública de abastecimento & 25 & 87,5 \\
\hline
\end{tabular}

Na tabela 7 , quando perguntados de onde vem a água utilizada nas residências, $25 \%$ dos alunos estudantes da escola de zona rural responderam que a mesma provém de nascente olho d'água, $50 \%$ de poço próprio e apenas $25 \%$ estão ligados a rede pública de abastecimento, ou seja, apenas $25 \%$ destes possuem água com algum tipo de tratamento, o que pode contribuir ao aumento do índice de doenças epidemiológicas.

Na escola de zona urbana, $12,5 \%$ dos alunos responderam que fazem uso de nascente olho d'água para obtenção de água e $87,5 \%$ estão ligados a rede pública de abastecimento. Em relação a qualidade da água consumida, surge um ponto preocupante, havendo a necessidade de um monitoramento mais eficaz, e planejamento para estender a $100 \%$ dos munícipes a rede de abastecimento e tratamento, sendo que $75 \%$ dos domicílios dos alunos de escola em área rural não possuem água tratada, o que aumenta o risco destes estarem consumindo água contaminada.

Tabela 8 - Para onde vai o esgoto produzido em sua casa?

\begin{tabular}{lll}
\hline & $5^{\circ}$ ano zona Rural $(\%)$ & $5^{\circ}$ ano Zona Urbana(\%) \\
\hline Fossa séptica - tratamento primário & 0 & 0 \\
Sumidouro - poço negro & 100 & 100 \\
\hline
\end{tabular}

Quando perguntados sobre o destino do esgoto produzido nas suas casas tabela $8,100 \%$ dos alunos, tanto da escola localizada em zona rural, quando na urbana responderam que a destinação do esgoto doméstico é o sistema de fossa sumidouro - poço negro, o que corrobora com os dados apontados no plano municipal de saneamento básico, $17 \%$ das famílias têm o esgoto em valas a céu aberto, características que contribuem para a contaminação do lençol freático conduzindo poluentes para consumo. 


\subsection{Escola Zona Urbana $3^{\circ}$ ano ensino médio e $9^{\circ}$ ano ensino fundamental}

Na segunda etapa da aplicação dos questionários, os mesmos foram aplicados nas mesmas escolas, as quais foram aplicados os demais, portanto com as turmas do $3^{\circ}$ ano do ensino médio da escola em zona urbana e $9^{\circ}$ ano do ensino fundamental da escola em zona rural. Nesta etapa foram aplicados um total de 16 questionários. Sendo escolhidas as turmas finais de cada nível, com maior numero de alunos matriculados, para realizar uma análise de sua trajetória, trazendo um comparativo de suas concepções sobre o tema em ambos os níveis de ensino.

Sendo aplicados seis questionários á turma de alunos do $9^{\circ}$ ano do ensino fundamental de uma escola em zona rural, com idades em 10\% entre 12 e 15 anos e $90 \%$ entre 15 e 18 anos, entre estes alunos, apenas $10 \%$ residem em zona urbana os demais $90 \%$ em zona rural. Os questionários foram aplicados, e conforme surgiam dúvidas e posicionamentos, os mesmos foram sendo relatados, com interação dos alunos. Os demais da turma de $3^{\text {o }}$ ano do ensino médio de uma escola em zona urbana as idades variam, sendo $90 \%$ entre 12 e 15 anos e $10 \%$ entre 18 e 20 anos, destes $30 \%$ residem em zona urbana e $70 \%$ em zona rural.

As questões foram elaboradas com uma linguagem mais especifica que os demais aplicados as turmas de quinto ano, levando em consideração o grau de conhecimento dos diferentes níveis de ensino entre as turmas.

Tabela 9- Qual sua concepção sobre educação ambiental:

\begin{tabular}{|c|c|c|}
\hline & $9^{\circ}$ ano Zona Rural $(\%)$ & $3^{\mathrm{o}}$ ano Zona Urbana (\%) \\
\hline $\begin{array}{l}\text { Estudo sem relevância, o qual não contribui } \\
\text { para sua vida. }\end{array}$ & 25 & 0 \\
\hline $\begin{array}{l}\text { Ramo da educação o qual traz como objetivo o } \\
\text { conhecimento sobre o meio ambiente e } \\
\text { utilização dos recursos naturais buscando a } \\
\text { sustentabilidade e a prevenção da perda de } \\
\text { qualidade ambiental. }\end{array}$ & 75 & 75 \\
\hline $\begin{array}{l}\text { Estudo com a realização de atividades e } \\
\text { pesquisas as quais não têm aplicabilidade em } \\
\text { seu cotidiano. }\end{array}$ & 0 & 0 \\
\hline $\begin{array}{l}\text { A educação ambiental está distante da minha } \\
\text { realidade, pois os maiores problemas estão nos } \\
\text { grandes centros. }\end{array}$ & 0 & 25 \\
\hline
\end{tabular}

Observa-se pela tabela 9, que para 75\% dos alunos da escola de zona rural, educação ambiental é o ramo da educação o qual traz como objetivo o conhecimento sobre o meio ambiente e utilização dos recursos naturais buscando a sustentabilidade e a prevenção da perda de qualidade ambiental, e para $25 \%$ é um estudo sem relevância, o qual não contribui para sua vida.

O percentual de $75 \%$ apontou como ramo da educação o qual traz como objetivo o conhecimento sobre o meio ambiente e utilização dos recursos naturais buscando a sustentabilidade e a prevenção da perda de qualidade ambiental, também para os alunos de $3^{\circ}$ ano do ensino médio da escola em zona urbana, portanto os demais $25 \%$ responderam a educação ambiental está distante da minha realidade, pois os maiores problemas estão nos grandes centros. 
Tabela 10 - De que forma é introduzida a prática de educação ambiental em seu cotidiano escolar?

\begin{tabular}{|c|c|c|}
\hline & 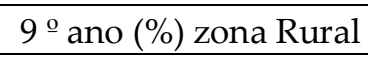 & $3^{\circ}$ ano (\%) Zona Urbana \\
\hline Pesquisas bibliográficas & 0 & 25 \\
\hline Palestras & 0 & 50 \\
\hline Trabalhos em grupo & 0 & 0 \\
\hline $\begin{array}{l}\text { Aulas com passeios em ambientes os quais } \\
\text { possibilitam o contato com a natureza e análise in } \\
\text { loco dos problemas e soluções }\end{array}$ & 100 & 25 \\
\hline
\end{tabular}

Conforme tabela 10, quando perguntados sobre a forma que é introduzida a prática de educação ambiental em seu cotidiano escolar, para 100\% dos alunos do $9^{\circ}$ ano as aulas são com passeios em ambientes os quais possibilitam o contato com a natureza e análise in loco dos problemas e soluções. Para 50\% dos alunos do $3^{\circ}$ ano, a educação ambiental, é introduzida com palestras, para $25 \%$ com pesquisas bibliográficas, e para os demais $25 \%$ aulas com passeios em ambientes os quais possibilitam o contato com a natureza e análise in loco dos problemas e soluções.

É válido salientar que quando questionados sobre a educação ambiental, os mesmos ficaram em dúvida sobre o tema, então foram orientados a analisar como qualquer ação, ou pensamento ligado a preservação do ambiente natural sendo estes processos que fazem parte da educação ambiental, a dúvida que os assolou de inicio, foi devido a realidade vivenciada em sala de aula, sendo existem lacunas na aplicação da politica nacional de educação ambiental, que dificultam o trabalho dos professores sobre o tema. Sendo estes apontados pelos mesmos e relatados nesta pesquisa.

Tabela 11 - Em sua residência existe coleta de resíduos/lixo?

\begin{tabular}{llc}
\hline & $9^{\circ}$ ano Zona Rural(\%) & $3^{\circ}$ ano Zona Urbana (\%) \\
\hline Sim & 0 & 30 \\
Não & 100 & 70 \\
\hline
\end{tabular}

Podemos analisar tabela 11, que $100 \%$ dos alunos do $9^{0}$ ano não possuem coleta de resíduos em seus domicílios, e para alunos do $3^{\text {o }}$ apenas $30 \%$ possuem coleta e $70 \%$ não disponibilizam deste serviço, ou seja, apenas os que residem em zona urbana, 30\% disponibilizam de coleta, sendo que estudam na zona urbana, mas residem na rural, o que corrobora com o plano municipal de saneamento básico que $78 \%$ dos domicílios não são contemplados com a coleta de resíduos domiciliares.

Tabela 12 - Você disponibiliza de água tratada em sua residência?

\begin{tabular}{|c|c|c|}
\hline & $9^{\circ}$ ano Zona Rural(\%) & $3^{0}$ ano Zona Urbana (\%) \\
\hline Sim & 100 & 75 \\
\hline Não & 0 & 25 \\
\hline
\end{tabular}

Em relação a disponibilidade de água tratada, tabela 12, quando perguntados, $100 \%$ dos alunos do $9^{\circ}$ ano possuem água tratada, o que diverge da realidade encontrada, nos alunos de $5^{\circ}$ ano também da zona rural, tal característica se dá devido a localização de suas residências dentro das macrozonas atendidas pelo abastecimento e tratamento da água. Já para os alunos do $3^{\circ}$ este percentual é inferior sendo de apenas $75 \%$, e $25 \%$ não disponibilizam deste recurso. 
Tabela 13 - Caso não, qual a forma de abastecimento utilizada?

\begin{tabular}{lcc}
\hline & $9^{\circ}$ ano Zona Rural $(\%)$ & $3^{\circ}$ ano Zona Urbana $(\%)$ \\
\hline Rio/córrego & 0 & 0 \\
Nascente olho d'água & 0 & 100 \\
Poço próprio & 0 & 0 \\
Captura da chuva & 0 & 0 \\
\hline
\end{tabular}

Para os alunos que não disponibilizam de água tratada, foi questionado, qual a outra forma de abastecimento que os mesmos dispõem, sendo que não usufruem de abastecimento, conforme tabela $13,100 \%$ dos alunos do $3^{\circ}$ ano que não disponibilizam de abastecimento, fazem uso de nascente ou olho d'água para obterem este recurso.

\subsection{Questionários aplicados aos educadores}

Foram aplicados questionários aos educadores de zona urbana que trabalham com $5^{\underline{0}}$ ano do ensino fundamental e $3^{\mathbf{o}}$ ano de ensino médio; e educadores de alunos de zona rural $5^{\circ}$ ano e $9^{\circ}$ ano, ambos do ensino fundamental, as visões dos mesmos divergem em relação a inserção da educação ambiental, mas ambos trazem como anseio a falha na aplicabilidade das legislações vigentes, principalmente da politica nacional de educação ambiental, as quais trazem métodos e resoluções que não estão em prática, caso estivessem trariam melhoria a aplicação deste tema. Tais anseios os mesmos relatam nesta pesquisa.

\subsubsection{Professores escola em zona urbana $x$ Professores escola zona rural}

\section{Você como educador, encontra dificuldades na inserção da educação ambiental. Caso sim,} quais?

Os educadores de zona urbana apontam dois pontos em ascensão, que dificultam a inserção de uma postura ambiental eficaz, o consumismo e o comodismo.

Conforme Guimarães (2007), que posiciona sobre a importância da postura ambiental para a sociedade, considerando que o futuro da humanidade depende de sua interação com o meio. E Donella (1997), que traz uma visão do comodismo em que a sociedade está inserida, água limpa sai da torneira e a suja vai embora pelo ralo, o lixo produzido diariamente é levado da frente das casas sem as pessoas terem a mínima preocupação de saber qual o seu destino.

Já os professores de zona rural relatam não ter maiores dificuldades para inserção deste tema, há retorno dos educandos nas atividades passadas. Os educadores reconhecem nas atividades diárias o uso dos conceitos aplicados em sala de aula, referentes a conscientização ambiental.

\section{Quais suas sugestões para uma maior amplitude na aplicabilidade deste estudo.}

Segundo os professores de zona urbana, para que haja um retorno mais significativo em relação aos temas abordados pela educação ambiental é necessário que a mesma se torne uma disciplina inclusa no currículo escolar, sendo que a e a politica nacional de educação ambiental deixa lacunas na aplicabilidade. O tema é de caráter transversal e interdisciplinar, mas os professores relatam que isto não ocorre, apenas na disciplina de ecologia, e almejam que se aplique em todos os níveis de escolaridade. 
Os professores de zona rural sugerem maior mobilização em dias especiais, como o dia do meio ambiente, da água, com atividades que envolvam toda a comunidade. Uso da tecnologia, com a montagem de um blog ou site, onde todas as atividades ficam a disposição de todos.

\section{Que ações poderiam ser tomadas para viabilizar esta inserção.}

Para os educadores de escola em zona urbana, deveriam ser trabalhados temas relacionados EA no currículo de todos os anos escolares, e realizar cursos preparatórios aos docentes e profissionais da educação.

Pode-se observar que a politica nacional de educação ambiental e demais resoluções que amparam a inserção deste tema não estão em ação, dificultando o trabalho dos profissionais de educação.

Sugerem os educadores de zona rural o uso de panfletos educativos, palestras, internet, sites, que possibilitem a divulgação para a comunidade e posteriormente ter uma amplitude maior. Projetos que envolvam a realidade do cotidiano dos alunos. Maior participação da comunidade em geral, e instrumentos para que a atenção dos mesmos se voltem para a necessidade do equilíbrio homem natureza.

\section{Quais ações você pratica em seu cotidiano em relação à educação ambiental.}

Os educadores de escola em zona urbana citam o cuidado com a disposição inadequada de resíduos, a busca por produtos que façam uso de poucas embalagens, menor consumo para menor geração de resíduos.

As ações dos professores de zona rural assemelham-se, tais como segregação correta dos resíduos, desligar as luzes, preservar a água, reaproveitando das águas da chuva e maquina de lavar.

\section{Como você considera as ações tomadas em âmbito municipal em relação ao meio ambiente.}

Os professores de escola em zona urbana, sugerem ações a serem implementadas, como a realização da coleta seletiva do lixo, disponibilizar mais lixeiras na praça, nos canteiros das ruas, a realização de palestras de conscientização nas escolas e para os munícipes.

Para os educadores de zona rural, há a realização de ações, porém poucas vindas do poder público municipal, pois ações em relação ao meio ambiente, segundo eles, devem existir sempre em qualquer instituição e em tempo continuo, devido a grande importância desse tema para nossa vida.

Pode-se observar que os educadores das escolas em zona rural encontram-se mais confiantes na aplicabilidade da educação ambiental, portanto ambos possuem sugestões para que haja um melhor desenvolvimento deste estudo. De outra forma os educadores da escola em zona urbana encontram mais dificuldades na inserção desta prática, ambos citam a necessidade de cursos preparatórios para os profissionais da educação.

No que refere a aplicabilidade da educação ambiental, podemos observar uma realidade que diverge a do Art. 3o da política nacional de educação ambiental, sendo que esta deve fazer parte de um processo educativo mais amplo, sendo que todos têm direito à educação ambiental, incumbindo:

I - ao Poder Público, nos termos dos arts. 205 e 225 da Constituição Federal, definir políticas públicas que incorporem a dimensão ambiental, promover a educação ambiental em todos os níveis de ensino e o engajamento da sociedade na conservação, recuperação e melhoria do meio ambiente;II - às instituições educativas, promover a educação ambiental de maneira integrada aos programas educacionais que desenvolvem; III - aos órgãos integrantes do Sistema Nacional de Meio Ambiente - Sisnama, promover ações de educação ambiental integradas aos programas de conservação, recuperação e melhoria do meio ambiente; IV aos meios de comunicação de massa, colaborar de maneira ativa e permanente na disseminação de informações e práticas educativas sobre meio ambiente e incorporar a dimensão ambiental em sua programação; $\mathrm{V}$ - às empresas, entidades de classe, instituições públicas e privadas, promover programas destinados à capacitação dos trabalhadores, visando à melhoria e ao controle efetivo sobre o ambiente de trabalho, bem como sobre as 
repercussões do processo produtivo no meio ambiente; VI - à sociedade como um todo, manter atenção permanente à formação de valores, atitudes e habilidades que propiciem a atuação individual e coletiva voltada para a prevenção, a identificação e a solução de problemas ambientais. (BRASIL,1999).

No que refere o Art.9o da política nacional de educação ambiental, esta deve ser desenvolvida em todas as instituições de ensino, englobando todos os níveis. Neste sentido pode-se observar que na prática existem inconformidades em relação ao cotidiano encontrado nas escolas com a legislação vigente.

Art. 9o Entende-se por educação ambiental na educação escolar a desenvolvida no âmbito dos currículos das instituições de ensino públicas e privadas, englobando: I - educação básica: a) educação infantil; b) ensino fundamental e c) ensino médio;II - educação superior; III - educação especial; IV - educação profissional; V educação de jovens e adultos. Art. 11. A dimensão ambiental deve constar dos currículos de formação de professores, em todos os níveis e em todas as disciplinas. Parágrafo único. Os professores em atividade devem receber formação complementar em suas áreas de atuação, com o propósito de atender adequadamente ao cumprimento dos princípios e objetivos da Política Nacional de Educação Ambiental (BRASIL,1999).

Pode-se analisar no que refere ao Art. 11 que também há divergência, o qual dimensiona a educação ambiental como imprescindível nos currículos de formação de professores, em todos os níveis e em todas as disciplinas. Conforme parágrafo único, os professores devem receber formação complementar independente da área de atuação para que os mesmos possam atender adequadamente ao cumprimento dos princípios e objetivos da Política Nacional de Educação Ambiental.

\section{Conclusões}

Após a busca por abranger os conhecimentos sobre a realidade local do município de Jacuizinho/RS, fazendo um comparativo com relatórios e outros documentos oficiais que caracterizam o município em questão, os quais esboçam a abordagem teórica deste trabalho, e a realidade encontrada, conclui-se que a inserção da educação ambiental nas escolas onde os alunos foram entrevistados vem sendo um desafio, portanto há_uma constante luta para superá-lo.

Observando os anseios dos professores, pode-se notar que existem algumas dificuldades na inserção da educação ambiental, relatada a necessidade de qualificação para que os mesmos obtenham segurança na aplicabilidade de suas aulas, que as legislações e diretrizes relacionadas como tema sejam aplicadas sem deixar lacunas. Sendo que os educadores vivem na eterna busca por conhecimento, o qual se faz necessário juntamente com a perseverança, para que haja uma maior amplitude na busca pela conscientização ambiental.

Os objetivos deste trabalho foram alcançados, os quais propunham verificar o conhecimento dos educandos e seus respectivos professores em relação a realidade ambiental de seu município, podendo afirmar que os mesmos conhecem tal realidade, e as trazem com clareza no preenchimento dos mesmos. Visto que, houve uma participação de $100 \%$ dos alunos e professores nas respostas aos questionários.

Ficou palpável a realidade e o conhecimento dos alunos e professores sobre os temas abordados, os quais foram personagens em foco nesta pesquisa, a qual poderá ser acrescida com a extensão destes questionamentos ás demais escolas e a comunidade para que seja possível analisar não apenas o âmbito escolar, mas a comunidade em geral, a respeito de suas opiniões sobre educação ambiental, se acreditam esta ser importante, e caso sim quais sugestões para que haja realmente a participação de todos. 
Verificou-se com clareza os pontos positivos e negativos encontrados em âmbito local os quais refletem em âmbito global e necessitam de uma abordagem ampla e criteriosa. Sendo que a inserção dos questionários possibilitou uma discussão ampla dos temas sobre a educação ambiental, atendendo $100 \%$ do objetivo de fomento deste tema nas escolas. Sendo este realizado através da inserção dos questionamentos, os quais trouxeram fatos a serem discutidos em conjunto.

Os resultados encontrados possibilitam conhecer a realidade ambiental do município de Jacuizinho/RS, e concepções de jovens em idade escolar e respectivos professores a respeito da educação ambiental. Sendo esta a ideia deste trabalho, o qual contribuiu para fomentar a discussão sobre educação ambiental, a qual percorre um caminho extenso e árduo, como qualquer outra ciência, exige paciência, estudo, trabalho e dedicação para ser compreendida e aplicada. Ilude-se quem desejar obter excelentes resultados sem trilhar essas etapas.

\section{Referências}

ALMEIDA, D. N.; LOPEZ, M. R. Q. O professor PDE e os desafios da escola pública paranaense. Paraná: Secretaria da Educação. V.1, 2012.

BRASIL. Política Nacional de Educação Ambiental. Lei n.9.795, de 27 de abril de 1999. Dispõe sobre a educação ambiental, institui a Política Nacional de Educação Ambiental e dá outras providências. Diário Oficial da Republica Federativa do Brasil, Brasília, DF, 27 abr.1999. Disponível em<http://portal.mec.gov.br/secad/arquivos/pdf/educacaoambiental/lei9795.pdf $>$. Acesso em: 02 jul. 2015.

BRASIL. Lei n. 12.305, de 2 de agosto de 2010. Institui a Política Nacional de Resíduos Sólidos. Presidência da República, Brasília, DF, 02 de agost. 2010. Disponível em: https://www.planalto.gov.br/ccivil_03/_ato2007-2010/2010/lei/112305.htm. Acesso em: 01 julho 2015.

BRASIL. Lei n. lei no 11.445 , de 5 de janeiro de 2007. Estabelece diretrizes nacionais para o saneamento básico; altera as Leis nos 6.766, de 19 de dezembro de 1979, 8.036, de 11 de maio de 1990, 8.666, de 21 de junho de 1993, 8.987, de 13 de fevereiro de 1995; revoga a Lei no 6.528, de 11 de maio de 1978; e dá outras providências. Presidência da República, Brasília, DF, 05 de jan. 2007. Disponível em: http://www.planalto.gov.br/ccivil_03/_Ato2007-2010/2007/Lei/L11445.htm. Acesso em: 01 jul. 2015.

BRASIL. Lei n. 9.433, de 8 de janeiro de 1997. Institui a Política Nacional de Recursos Hídricos.

Presidência da República, Brasília, 08 de janeiro de 1997. Disponível em: http://www.planalto.gov.br/ccivil_03/Leis/L9433.htm. Acesso em: 01 jun. 2015.

BRASIL. Secretaria de Educação Fundamental. Parâmetros Curriculares Nacionais: Meio

Ambiente. Brasília: MEC/SEF, $1998 . \quad$ Disponível http://portal.mec.gov.br/seb/arquivos/pdf/meioambiente.pdf. Acesso em: 01 jun. 2015.

COELHO, R. M. P. Fundamentos em ecologia. Porto Alegre: Artmed. 2007. 12p.

CZAPSKI, S.A. Implantação da educação ambiental no Brasil. Brasília: Ministério de Educação e do Desporto, 1998, 166p.

DUVOISIN, Ivane; SOUZA, Moacir Langoni de; GALIAZZI, Maria do Carmo. A pesquisa em sala de aula como metodologia para complexificar o discurso ambiental. Contraponto, Itajaí, v. 3, n. 1, p. 69 80, 2003. Disponível em: http://siaiweb06.univali.br/seer/index.php/rc/article/view/707/558. Acesso em: 01 ago. 2015. 
GUIMARÃES, M. A dimensão ambiental na educação. Campinas, SP; Papirus, 1995, - (Coleção Magistério: Formação e Trabalho Pedagógico) 8 ed., 2007.

GRUENER, C. G.; DALLACORTE, F. Relação entre Meio Ambiente, Tecnologia, Cultura e Sociedade. Blumenau: Iade Publicações, 2011.

JACUIZINHO. Diagnóstico. Plano Municipal de Saneamento Básico. Latus: 2014.

JACUIZINHO. Plano Municipal de Meio Ambiente. Latus: 2011.

PADUA, S.; TABANEZ, M. (organizadoras). Educação ambiental: caminhos trilhados no Brasil. Brasília: Instituto de Pesquisas Ecológicas (IPÊ), 1997.

RIO GRANDE DO SUL. Secretaria Estadual Do Meio Ambiente Do Estado Do Rio Grande Do Sul. Inventário Florestal Contínuo do Rio Grande do Sul. Disponível em: www.sema.rs.gov.br. Acesso em: 27 mai. 2015.

SCHARF, Regina. Manual de Negócios Sustentáveis. São Paulo, Amigos da Terra, 2004.

SNIS - SISTEMA NACIONAL DE INFORMAÇÕES SOBRE SANEAMENTO BÁSICO. Período 2013. Disponível: http://www.snis.gov.br/PaginaCarrega.php?EWRErterterTERTer=105. Acesso em: 27 mai. 2015. 